NBER WORKING PAPER SERIES

\author{
DEMAND SHIFTS, POPULATION \\ ADJUSTMENTS, AND LABOR MARKET \\ OUTCOMES DURING THE 1980S
}

\author{
John Bound \\ Harry J. Holzer
}

NBER Working Paper 5685

\author{
NATIONAL BUREAU OF ECONOMIC RESEARCH \\ 1050 Massachusetts Avenue \\ Cambridge, MA 02138 \\ July 1996
}

An early version of this paper was prepared for the Poverty Research Seminar sponsored by the Institute for Research on Poverty (University of Wisconsin) and the U.S. Department of Health and Human Services in May, 1994. Much of the work on the current version was completed while both authors were visiting scholars at the Russell Sage Foundation. We would like to thank the Poverty Institute, the Bureau of Labor Statistics, and the University of Michigan for their financial support of this work. We would also like to thank Susanna Loeb, Jess Reaser, and Sarah Turner for excellent computational assistance. Helpful comments were provided by seminar participants at the National Bureau of Economic Research, the Economic Demography group at the Population Association of America meetings, the Russell Sage Foundation, Baruch College, Columbia University, Princeton University, and the Federal Reserve Bank of New York. We are especially grateful to Timothy Bartik, Charlie Brown, Chinhui Juhn, Jim Rauch, Sarah Turner, and Hal Winsborough for helpful comments, to Bartik for providing us local employment data, to Lisa Neidert for help with the census data, and to Sandra Crump for help with preparation of the manuscript. This paper is part of NBER's research program in Labor Studies. Any opinions expressed are those of the authors and not those of the National Bureau of Economic Research.

(C) 1996 by John Bound and Harry J. Holzer. All rights reserved. Short sections of text, not to exceed two paragraphs, may be quoted without explicit permission provided that full credit, including $\odot$ notice, is given to the source. 


\title{
DEMAND SHIFTS, POPULATION \\ ADJUSTMENTS, AND LABOR MARKET \\ OUTCOMES DURING THE 1980S
}

\begin{abstract}
In this paper we explore the effects of labor demand shifts and population adjustments across metropolitan areas on the employment and earnings of various demographic groups during the 1980s. Results show that, although earnings and employment deteriorated for less-educated and black males in most areas in the 1980s, there was a good deal of geographic variation in the magnitudes of these changes. Shifts in labor demand across local areas contributed to this variation, and had greater relative impacts on the earnings and employment of these demographic groups. We also find that population shifts across areas, presumably due to migration, at least partially offset the effects of these demand shifts. But less-educated workers showed substantially lower population adjustments in response to these demand shifts. These limited supply responses apparently contributed importantly to relatively greater deterioration of employment and earnings of these groups in declining areas during the 1980s.
\end{abstract}

John Bound

Department of Economics

University of Michigan

611 Tappan Street

Ann Arbor, MI 48109-1220

and NBER
Harry J. Holzer

Department of Economics

Michigan State University

101 Marshall Hall

East Lansing, MI 48824 


\section{Introduction}

It is by now well known that the eamings and employment rates of less-educated workers and blacks in the United States suffered during the 1980s in both relative and real terms. Some consensus on the causes of these declines has begun to emerge in the research literature. Specifically, the demand for less-educated labor has declined for a variety of reasons, while the growth in supply of educated labor has slowed (e.g., Bound and Johnson 1992; Katz and Murphy 1992). In addition, there appears to be major geographic variation in both the extent of these demand shifts and the changes in labor market outcomes that they have caused for these different groups. For instance, Topel (1994) and Karoly and Klerman (1994) have pointed to major regional variation in employment and earnings outcomes for less-educated workers. Bound and Freeman (1992) found that during the 1980s between blacks and whites grew most rapidly in the North-Central region where employment and earnings were declining more generally.

There are a variety of reasons for the declining employment status of less-educated and black workers in particular markets, especially those experiencing declining employment overall. Shifts in labor demand away from these groups might be greater in areas with declining overall employment either because they are highly industrialized areas and industry is declining, or because these workers are highly concentrated in declining industries. Alternatively, differences in supply shifts might play an important role. In particular, out-migration from declining areas and immigration to growing ones may be slower for minorities or less-educated groups, who would then be more hurt by demand shifts away from particular areas, even if the shifts themselves were skill-neutral (Topel 1986). Indeed, the tendency for eamings and employment inequality across groups to worsen in areas where overall employment levels are declining (e.g., Freeman 1982, 1991, Bartik 1991, 1992 is consistent with both the relative demand and the relative supply adjustment explanations. 
On the demand side, areas in which manufacturing accounts for a disproportionate share of employment (such as the Midwest) suffered large employment losses in that industry and overall during the 1980s. The pro-cyclical nature of the construction industry implies that it too will lose more than its proportionate share of employment in declining labor markets. As these are both industries in which less-skilled workers have traditionally been heavily represented and relatively well-paid, their earnings and employment declined more than proportionately in areas where overall labor demand was declining. Given the heavy concentration of blacks in centralcity manufacturing jobs in the Midwest during the 1970s, this should have been (and apparently was) particularly true for them. ${ }^{1}$ In addition, the effects of any given demand shift might be relatively more adverse for the more "marginal" groups (such as blacks, the young, or the leastskilled workers) within any industry or area. ${ }^{2}$

On the supply side, lower geographic mobility among older and/or less-educated workers has been widely documented (e.g., Schwartz 1973; Greenwood 1975; and Long 1988). Migration rates have been lower among blacks than whites over the last three decades (Lansing and Mueller 1967; U.S. Commerce Department 1981), although the opposite was true around the period of the two World Wars and in the 1920s (primarily because of the exodus of blacks from the rural South to the urban North). However, we have very little evidence to date on differences across groups in population adjustments to demand shifts, or on the implications of

'Particularly negative effects of declining manufacturing employment (especially in the central cities) on the earnings and/or employment of black males have been found by Kasarda (1989), Acs and Danziger (1992), Bluestone et. al. (1992), Bound and Freeman (1992), Bound and Holzer (1993), Holzer and Vroman (1992), and Johnson and Oliver (1992). Juhn (1994) focuses on the effects of industrial structure on less-educated males more generally.

${ }^{2}$ The effects of overall labor demand shifts on the relative demand for skilled and unskilled labor will also depend on a variety of other factors such as the degree to which capital and skilled labor are complements, the relative mobility of capital and labor, the extend to which technological change is embodied in capital, and the extent to which technological change is skill-biased. 
these differences for relative changes in employment and earnings. ${ }^{3}$

Supply adjustments through migration in response to local demand shifts have been analyzed in some recent studies. Bartik (1991) and Blanchard and Katz (1992) have found substantial mobility in response to demand shocks. Blanchard and Katz suggest that the impact of these shocks (in terms of employment rates and wage levels) should be completely dissipated in less than a decade because of population adjustments, while Bartik's work suggests somewhat greater persistence. ${ }^{4} \quad$ But these studies all used aggregate measures of the overall population in local areas when measuring adjustment processes, without differentiating by race or education.

In this paper, we present evidence on these issues for the period of the 1980s. After documenting the demographic and geographic variation in labor market outcomes and local demand and supply shifts during this period, we estimate the effects of demand shifts on wage and employment changes for a variety of demographic groups (defined by education and experience as well as race and gender). We also analyze differences across these groups in population adjustments to these demand shifts, and how these supply adjustment differences might have contributed to observed differences in relative wages.

To analyze labor market and population outcomes at the local level for such detailed demographic groups, we use data from the Public Use Micro Samples (PUMS) of the Census of Population in 1980 and 1990 . We use the 5\% samples for each of these years, which give us vastly more individual observations with which to disaggregate outcomes by demographic group. Furthermore, the PUMS data enable us to analyze demand/supply shifts as well as outcomes

\footnotetext{
${ }^{3}$ mong the earlier studies, only Lansing and Mueller analyze differences across education and racial groups in the responsiveness of migration rates to personal experiences of unemployment or income loss as well as local area unemployment. But they provide no general measures of responsiveness to labor demand shifts; and their results are quite dated (as they are based on survey data from the early 1960s).

${ }^{4}$ See Bartik (1993) for a discussion of possible explanations for the discrepancy between his estimates and those of Blanchard and Katz.
} 
across metropolitan areas, rather than at the much broader state or regional levels that others have examined using data from sources such as the Current Population Survey (CPS). ${ }^{5}$ On the other hand, the analysis of cross-area changes over a single decade (rather than annual time-series analysis of broader geographic units) prevents us from studying the dynamics of the adjustment process that has been the focus of earlier work (e.g., Topel 1986; Bartik 1991; Blanchard and Katz 1992).

Our primary results are these: (1) While relative wage and employment declines for the less-educated occurred in most MSAs, these effects were much more severe in some areas (such as the industrial centers of the Midwest) than others. (2) Local labor demand shifts contributed to the deteriorating outcomes of these groups in declining areas. The effects of demand shifts on wages and employment were greatest among the young, the less educated, and black workers. (3) Population adjustments did occur in response to labor demand shifts in the 1980s, with workers moving out of declining areas into growing ones. But less-educated workers had relatively low rates of migration in response to these demand changes; and there is some evidence that this was also true for blacks, even within educational groups. The limited adjustments in labor supply for these groups appear to have contributed importantly to the relatively greater deterioration of their employment and earnings in declining areas during the 1980s.

\section{Hypotheses, Data, and Equations}

\section{A. Conceptual Framework}

To aid in the interpretation of our empirical work we start by developing a simple model

\footnotetext{
${ }^{5}$ We abstract here from intra metropolitan shifts in the location of employment or population, of the type that as been emphasized in the literature on "spatial mismatch" (e.g., Holzer 1991).
} 
of local labor markets. Our notion is that for historical reasons different metropolitan areas specialize in the production of different goods (e.g., Detroit has been the center of the auto industry, which they then "export" to other areas (Krugman 1991). Thus, the kind of demand shocks that hit the U.S. during the 1980s (e.g., the decline in the auto industry) will have differential effects on local areas. At the same time, demand shocks to a metro area's export industries will have spillover effects on other sectors of the local economy (e.g., the shutdown of an auto plant will affect local service industries as well). The combined effects of the initial demand shock to the export sector and these spillover effects will then determine the overall effects of these shocks on the relative demand for skilled and unskilled labor in the local area.

Consider the economy in metro area $k$. Using constant returns to scale, technologies firms produce both for export, $X_{k}$, and for local consumption, $C_{k}$, using skilled $\left(L_{s_{k}}\right)$ and unskilled $\left(L_{\mathrm{u}_{k}}\right.$ ) labor. In the short term, labor is supplied exogenously to a local area, but it is mobile across industries. The area also imports $M_{k}$. Factor and product markets are competitive. While incorporating either sector-biased of factor-biased technological change into our model would be straightforward (Jones 1965), doing so would complicate the model considerably without affecting its basic implications. For this reason we assume fixed technologies.

Let $Y_{i j_{k}}$ represent the share of the $i_{t h}$ demographic group's workforce employed in the $j_{t h}$ sector $\left(\Sigma_{j} Y_{i j_{k}}=1\right)$, and $S_{i j_{k}}$ represent the $i_{t h}$ skill group's share of the total wage bill in the $j_{t h}$ sector $\left(\sum_{i} S_{i j_{k}}=1\right)$. While not essential to the model, to help fix ideas we will also assume that the export sector is intensive in unskilled labor $\left(\mathrm{Y}_{u x_{k}}>\mathrm{Y}_{s x_{k}} ; S_{\mathrm{ux}}>S_{\mathrm{uc}}\right) .^{6}$ It will be useful to have notation for the differences in factor intensities. Define

\footnotetext{
${ }^{6}$ This will tend to be true for metro areas that "export" manufactured goods, but not necessarily those that export services (e.g., Omaha and Hartford export insurance).
} 
$d Y_{k}=Y_{u x_{k}}-Y_{s x_{k}}=Y_{S c_{k}}-Y_{u c_{k}}$ and $d S_{k}=S_{u x_{k}}-S_{u c_{k}}=S_{S C_{k}}-S_{S x_{k}}$

If we let $w_{s_{k}}$ and $w_{u_{k}}$ represent the wages of skilled and unskilled labor, $p_{x_{k}}$ and $p_{c_{x}}$ the prices of exports and local consumption goods (in terms of the price of imports), and dots over variables the percent changes in those variables, then:

$$
\begin{aligned}
& \left(Y_{s c_{k}} \dot{C}_{k}+Y_{s x_{k}} \dot{X}_{k}\right)-\dot{L}_{s_{k}}=\delta_{s_{k}}\left(\dot{w}_{s_{k}}-\dot{w}_{u_{k}}\right) \\
& \left(Y_{u c_{k}} \dot{C}_{k}+Y_{u x_{k}} \dot{X}_{k}\right)-\dot{L}_{u_{k}}=-\delta_{u_{k}}\left(\dot{w}_{s_{k}}-\dot{w}_{u_{k}}\right)
\end{aligned}
$$

where $\delta_{i_{k}}$ represents the aggregate percentage saving in the $i_{t h}$ input at unchanged outputs associated with a 1 percent rise in the relative wages of the $i_{t h}$ input. The $\delta s$ are themselves functions of the elasticities of substitution between the two labor inputs in the two sectors. The terms in parentheses on the left of (1) and (2) represent shifts in the demand for the two labor inputs. Subtracting (2) from (1) gives:

$$
\left(d Y_{k} \dot{C}_{k}-d Y_{k} \dot{X}_{k}\right)-\left(\dot{L}_{s_{k}}-\dot{L}_{u_{k}}\right)=\left(\delta_{s_{k}}+\delta_{u_{k}}\right)\left(\dot{w}_{s_{k}}-\dot{w}_{u_{k}}\right)
$$

Shifts in the industrial composition of a local area or shifts in the composition of the workforce affect the relative wages of skilled and unskilled workers in similar ways. Output prices are a share-weighted linear combination of the shift in wages of skilled and unskilled labor inputs:

$$
\begin{aligned}
& S_{s c_{k}} \dot{w}_{s_{k}}+S_{u c_{k}} \dot{w}_{u_{k}}=\dot{p}_{c_{k}} \\
& S_{s x_{k}} \dot{w}_{s_{k}}+S_{u x_{k}} \dot{w}_{u_{k}}=\dot{p}_{x_{k}} .
\end{aligned}
$$

Together, equations (1)-(5) describe the production side of the model. To close the model we need to specify the demand for output and inputs. For simplicity, we assume that consumers in the $k_{t h}$ metro area have Cobb-Douglas utility functions and spend a constant share of their 
income, $\alpha$, on $C_{k}$ (and the rest on $M_{k}$ ). The implication of this assumption is that:

$$
\left(\dot{C}_{k}-\dot{X}_{k}\right)=-\left(\dot{p}_{c_{k}}-\dot{p}_{x_{k}}\right)
$$

Equations (1)-(6) determine relative wages and prices and hence output and factor allocations. In particular, shifts in the supply of skilled and unskilled labor have deterministic effects on product and factor prices as well as on output:

$$
\begin{aligned}
& \left(\dot{X}_{k}-\dot{C}_{k}\right)=\frac{1}{d Y_{k}} \cdot \frac{1}{\sigma_{s_{k}}+1}\left(\dot{L}_{u}-\dot{L}_{s}\right) \\
& \left(\dot{p}_{x_{k}}-\dot{p}_{c_{k}}\right)=-\frac{1}{d Y_{k}} \cdot \frac{1}{\sigma_{s_{k}}+1}\left(\dot{L}_{u}-\dot{L}_{s}\right) \\
& \left(\dot{w}_{u_{k}}-\dot{w}_{s_{k}}\right)=-\frac{1}{d Y_{k}} \cdot \frac{1}{d S_{k}} \cdot \frac{1}{\sigma_{s_{k}}+1}\left(\dot{L}_{u}-\dot{L}_{s}\right)
\end{aligned}
$$

where $\sigma_{s_{k}}=\frac{\delta_{u_{k}}+\delta_{s_{k}}}{d \bigvee_{k} d S_{k}}$.

The demand for exports is a function of their price and a demand shifter :

$$
\dot{X}_{k}=\dot{\theta}_{k}-€ \dot{p}_{x_{k}}
$$

where $\epsilon$ represents the elasticity of demand for $X_{k}$ and $\theta_{k}$ the demand shifter. The effects of a demand shock to exports $\left(\theta_{k}\right)$ on local labor demand in this model can be either skill-biased or skill-neutral. On the one hand, negative (positive) demand shocks alone will shift demand away from (toward) skilled labor in that area, and will therefore raise (lower) the relative wages of skilled workers there. But local spillover effects on the demand for the non-traded good will tend to neutralize the skill-bias of the original shock. 
Under the assumption of Cobb-Douglas utility functions, demand shocks raise the price of locally produced goods (both $C_{k}$ and $X_{k}$ ) and thus wages by $\dot{\theta}_{k} / \epsilon$, but leave relative wages and the allocation of inputs across sectors alone (due to the constancy of consumers' income shares spent on $C_{k}$ ). The cost of living rises by a fraction, $\alpha$, of the rise in wages. Thus positive demand shocks leave local area workers better off, while negative demand shocks have the opposite effect. Under different assumptions about the nature of the local demand for goods, demand shocks will affect the relative demand for skilled and unskilled labor, with the net effect depending, among other things, on the degree of substitutability between locally produced and imported goods and services.

Regardless of whether or not the net effect of the demand shift in the local area is skillbiased, positive overall demand shocks to a local area will create incentives for labor to migrate there from other areas, while negative shocks will create incentives for labor to migrate out. As Topel has emphasized (1986), the magnitudes of such supply shifts will depend on expectations of the future (shocks that are expected to persist will have larger effects) and on the costs of moving. To the extent that such costs and therefore migration rates vary across skill groups, demand shocks that do not affect the relative demand for skilled and unskilled labor in an area will still have effects on relative wages there through their effects on the relative local supplies of different kinds of labor. Thus, negative demand shocks to an area will lead to growing inequality across demographic groups if geographic mobility is higher among the more highly skilled groups.

The latter possibility is illustrated in Figure 1. Here we find a negative overall labor demand shift (of magnitude AI) away from a particular local market that equally affects unskilled 
and skilled workers (denoted by $u$ and $s$ respectively). ${ }^{7} W_{0}$ and $L_{0}$ denote starting wage and employment levels for both groups (which have been set equal here for the sake of simplicity).

But workers from both groups migrate away from this area. In this case, the magnitude of the resulting labor supply shift among skilled workers $(C D)$ exceeds that for unskilled workers $(F G)$, as does the change in total employment levels ( $B D$ and $E G$ respectively). But this also results in smaller wage losses for the skilled $(A B$ v. $A E)$ as well as smaller average employment losses among those who remain in the area $(B C$ v. $E F)$.

Thus, groups with more limited population mobility should show greater wage and employment rate deterioration in local areas when negative local demand shifts occur. Alternatively, these groups will experience greater wage and average employment increases in areas where labor demand is growing. If mobility is correlated with skills or income levels, labor market inequality will move inversely with local demand growth.

\section{B. Empirical Specification and Data}

We test these notions first by estimating reduced-form equations for the effects of overall demand shifts across local area on labor market outcomes and labor supply adjustments for various groups in those areas. With these estimates, we hope to gauge the extent to which overall demand shocks differentially affect various segments of the workforce, without trying to distinguish between various possible explanations for such effects. Subsequently, we try to estimate the extent to which differential supply adjustments to these demand shocks might explain the differential wage outcomes we find between more- and less-educated workers across

\footnotetext{
${ }^{7}$ The overall demand shift includes the initial effects (induced by product demand shifts) as well as any spillover effects, including those induced by labor supply responses. We abstract away from differences in the demand elasticities for the two kinds of labor.
} 
these areas.

We have analyzed data for 132 metropolitan statistical areas (MSAs) from the 1980 and 1990 PUMS files of the U.S. Census. In order to have consistent definitions of our geographic areas over time, we use the 1990 definitions of metropolitan areas in terms of counties in both years. ${ }^{8}$ While these definitions are more geographically inclusive than are those from earlier time periods (especially for a few MSAs such as Boston and New York), our empirical estimates do not appear to be strongly affected by these changes. ${ }^{9}$

We have two measures of changes in labor market outcomes for various demographic groups that we try to explain below: hourly wages and average per capita annual hours of employment. In addition we measure population adjustments for each group with changes in population size, and we measure total labor adjustment with changes in total hours worked (which is defined as population $x$ annual hours for the group). All of these are measured as changes in logs between 1979 and 1989. These four outcome measures are the dependent variables in our reduced-form equations, estimated across MSAs, for the effects of overall labor demand shifts across local areas.

All of the above variables are defined for the non-enrolled, non-institutionalized civilian population above the age of 16 . Most results below are presented by education level (i.e., for workers with college or more versus high school or less) and experience (less than 10 years versus all groups) as well as by race and gender within education and experience groups.

The kinds of overall local labor demand shifts represented by AI in Figure 1 are not

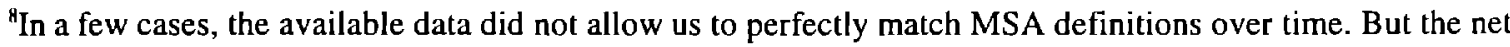
changes in population attributable to these matching problems rarely account for more than a few percentage points of the original population.

${ }^{9}$ Estimates that we generated using the 1970 rather than the 1990 definitions of MSAs in both years were quite similar to those presented below.
} 
directly observable. Therefore we use total local employment growth as a proxy for such demand shifts. But an additional problem here is that total employment growth in the MSA can be driven by shifts in local labor supply (through population growth, etc.) as well as demand. Therefore, following Bartik as well as Blanchard and Katz, we create an index for demand based on nationwide employment growth in industries, weighted by the MSA-specific employment shares in those industries - i.e.,

$$
\hat{n}_{k}=\sum_{j} Y_{j k} n_{j}
$$

where $\hat{n}_{k}$ represents predicted employment growth in the area, $Y_{j k}$ represents the share of total hours worked accounted for by sector $j$ in MSA $k$ (averaged over the beginning and end of the decade), and $n_{j}$ represents the change in the log of total hours of employment in the same sector nationally over the decade. ${ }^{10}$ Sectors are defined on the basis of 47 roughly two-digit industry cells.

The index is a weighted average of employment growth during the 1980s in each MSA, where the weights represent the different distributions of employment across sectors in each MSA." They measure the extent to which demand was shifting away from the industries in which workers were employed. The index should capture exogenous shifts in local labor demand that are predicted by the city-specific industry mix, while avoiding the endogeneity associated with local employment growth rates. We use this index as an instrument for the overall local employment growth. As a point of comparison, we also present some equations in which our outcome measures are regressed on total employment growth in the MSA estimated by OLS.

\footnotetext{
${ }^{10}$ Essentially, $\hat{n}$, represents the share component in the kind of shift- share analysis often performed by urban economists when studying metropolitan growth (Bradbury, Downs, and Small 1982; Terkla and Dorringer 1991; Coulsen and Rushen 1995.

${ }^{11}$ Variation in $\hat{\eta}_{k}$ arises primarily due to variation in the fraction of a metro area's workforce in manufacturing. The correlation between these two variables is 0.75 .
} 
Given the fact that we are examining changes that occur over the space of a decade, it is not possible for us to distinguish between the short-run and long-run effects of demand shocks in the way that those using annual data have done (Bartik 1991; Blanchard and Katz 1992).

Intuitively, it seems natural to assume that our estimates represent some kind of average between the two. ${ }^{12}$ Furthermore, the major demand shocks to local areas in the 1980s (e.g., the negative shocks to the industrial areas of the Midwest) occurred toward the beginning of the decade and persisted throughout it. Thus, changes in labor market outcomes over the course of the decade should reflect the decadal responses to these shocks. ${ }^{13}$

Finally, we note the procedures by which all of these equations were estimated. We began by categorizing individuals into cells on the basis of six education groups, four experience groups, and eight race-by-gender groups within each MSA in each census year. ${ }^{14}$ Changes in labor market outcomes and in supply adjustments were then defined for each cell and regressed on a set of dummies for MSAs and demographic groups. In particular, letting $y_{i j l m k}$ represent the change in an outcome for the $i_{t h}$ education, the $j_{t h}$ experience, the $I_{t h}$ race and the $m_{t h}$ sex group in the $k_{t h}$ metro area, we estimate equations of the form.

$$
y_{i j l m k}=\alpha_{i j l m}+\beta_{k}+u_{i j l m k}
$$

\footnotetext{
${ }^{12}$ In fact, Bartik (1993) has shown for a model similar to our own that, under plausible assumptions, long difference estimated effects will represent a weighted average of the long-run and short-run effects estimated from a distributed lag model. The required assumption is that changes over time in the explanatory variable (in our case employment growth) have to be positively correlated (i.e., across MSAs, those areas that are growing more rapidly early in the period will be doing so throughout it). Using ES-202 data provided to us by Bartik, we confirmed that this condition is, in fact, true for our MSAs over the 1979-1989 period.

${ }^{13}$ Oil price shocks did not follow this general pattern. For this reason, one might imagine that our model would not apply very well to metro areas in the Southwest that are heavily dependent on oil. We estimated many of our equations on samples that eliminated metro areas located in Texas, Oklahoma, and Louisiana. These results differed negligibly from those presented below.

${ }^{14}$ The education groups were based on the following numbers of completed years of schooling: 0-8, 9-11, 12 , 13-15, 16, and 17 or more. Experience groups are 0-9, 10-19, 20-29, and 30 or more. The race-by-gender groups include Hispanics and a residual category as well as white and black non-Hispanics.
} 
Regressions were weighted using the shares of the relevant demographic group in total hours worked in the MSA, averaged between 1979 and 1989. Earnings weights produced virtually identical results. These regressions were run separately for each of the subgroups for whom we present separate results below -- i.e., by education (college or more versus high school or less) and experience ( $0-9$ years versus all levels), and then for white and black males and females within each educational group. ${ }^{15}$

Coefficients on the MSA dummies (the $\beta_{k} s$ ) can then be interpreted as average local wage, employment, and population shifts, standardized for demographic differences across areas in the composition of local area workforces. These dummies were then regressed on the demand and/or supply measures to generate the results that are reported below. The second-stage regressions were weighted using the share of overall population in the sample accounted for by the MSA (averaged between 1980 and 1990). ${ }^{16}$ This two-stage procedure was used to take account of the multi-level nature of our data (Amemiya 1978). Standard errors are corrected for potential heteroskedasticity using procedures proposed by White $(1980,1982)$, among others. ${ }^{17}$ Since all dependent and independent variables are measured as changes in logs, all coefficients can be interpreted as elasticities.

\section{Results}

\section{A. Summary}

Summary data on changes in the logs of our four outcome measures over the 1980s

\footnotetext{
15 In all tabulations and estimated equations for specific race-by-gender subgroups within education and/or experience groups, we limited the sample to the 87 MSA's with no race-by-gender of less than 250 .

${ }^{16}$ For comparability across groups, we used the same MSA weights for the analysis of all subgroups.

${ }^{17}$ Eicher-White standard errors are known to be biased in small samples. Mackinnon and White (1985) argue in favor of Jackknife standard errors. Using our data, we compared the two for the models reported in Tables 3 and 6. In all such cases, Jackknife and Eicher-White standard errors are very similar.
} 
appear in Table $1 .{ }^{18}$ Separate estimates are presented by education and experience group, and also by race and gender within those categories. The results are generally consistent with those that have previously appeared in the literature on recent trends in earnings inequality (see Footnote 1). Less-educated workers suffered substantial declines in their real wages during this period, both in absolute terms and relative to those with college degrees. Hours worked also grew for the more-educated relative to the less-educated. Both wage and hours changes are more positive for females than for males, and for whites than for blacks within each gender and education/experience group.

In fact, less-educated black males lost roughly 6-7\% in annual earnings relative to lesseducated white males, even though the latter experienced real earnings losses as well; while lesseducated black females lost $18 \%$ in annual earnings relative to white females in all experience groups combined (and somewhat less among the least-experienced). Overall, the generally positive correlation between wage and hours worked changes across race, gender, and education groups suggest a primary role for relative labor demand shifts in generating these outcomes.

Population changes also exhibit some interesting relative patterns. We generally find declining relative population growth for the less-educated within each race-by-gender group, reflecting the demographic effects of rising school enrollment rates over time. These trends are particularly strong among white females, for whom the declines in population among the lesseducated are much sharper than they are for males. The rise in relative educational attainment for white females likely contributed to the change in their position in the labor market. ${ }^{19}$

\footnotetext{
${ }^{18}$ Nominal wages in this table have been deflated using changes in the national CPI-U-X1 over this period.

${ }^{19}$ The data also indicate that the growth in population with college or more education was relatively lower among blacks than whites. See Hauser (1993) and Kane (1994) for more evidence on this topic. But there was also a more pronounced rise in high school graduation rates and in the fractions of people with 1-3 years of college among blacks that are not apparent in these data, thus resulting in changes in average educational attainment that are more comparable
} across the two groups. 
Evidence on the geographic variation in our supply and demand shift measures and in wage and employment outcomes appears in Figure 2 and Table 2. Figure 2 graphically presents wage growth for high school and college graduates for MSAs with 1990 populations of over 2.5 million. Table 2 presents data for the 21 MSAs in our sample with populations of 1 million or more in 1990 and for which local price indices were available. ${ }^{20}$ The real wage and hours outcomes are presented by education group and for less-educated white and black males. The demand measures presented include shifts in total demand (as defined above) as well as changes in the shares of employment accounted for by manufacturing and construction. The supply measure presented is the relative change (i.e., difference in logs) in total hours worked between college graduates and those with high school or less education. As with our measures of total demand shifts, we present predicted values of these relative hours changes, based on equations in which they are regressed on the $\hat{n}_{k}$ measures; thus we are measuring relative supply responses to exogenous demand shifts (rather than overall supply changes). ${ }^{21}$

The data in Figure 2 and Table 2 show that both wage and hours changes for the collegeeducated exceeded those for high school graduates in virtually all of these MSAs, and changes in outcomes for white males exceeded those for black males in most cases as well. However, there appears to be considerable geographic variation in these outcomes. We find relatively strong wage growth for the less-educated in such areas as Boston and New York, while it was weakest in traditional industrial areas such as Pittsburgh, Detroit, Cleveland, and Chicago (as well as in

\footnotetext{
${ }^{20}$ There are 23 MSAs with population above 1 million in 1990 but local price data are not available for either Phoenix and Tampa, so these MSAs have been omitted from Table 2 and Figure 2.

${ }^{21}$ The reasons for presenting the predicted rather than the actual supply changes here are discussed more fully in Section $\mathrm{C}$ below. The magnitudes of relative supply shifts are all greater than those of relative demand shifts since the latter measure only between-industry components of increases while the former measure total increases.
} 
Houston). ${ }^{22}$ Less-educated black males did particularly poorly in all of the areas in which the relative earnings of high school workers fell.

The increases in the relative supply of college graduates and in total demand were somewhat larger in Boston and New York than in the industrial areas, while the growth in the relative demand for college graduates and the declines in manufacturing employment were generally smaller in the former. More generally, we find relatively strong simple correlations (above .6 in absolute value) between relative wage changes and our relative supply (or total demand) variables.

\section{B. Reduced Form Estimates}

Tables 3 and 4 present the results of reduced-form equations estimated across MSAs, in which our two labor market outcome measures and two supply adjustment measures are the dependent variables, and overall employment growth in the MSA is the independent variable. Estimates appear separately by education and experience group in Table 3, and also by race and gender within those groups in Table 4.

Results in Table 3 are presented for both OLS and Instrumental Variables (IV) estimation (where the latter uses the $\hat{n}_{k}$ measure as the instrument for total local employment growth), while Table 4 presents them only for IV. ${ }^{23}$ It is of some interest to examine the first stage equation for our estimates. Both the reliability and validity of our IV estimates depend on the reliability and validity of the first-stage estimates (Nelson and Startz 1990a,b; Bound, Jaeger, and Baker 1995). Furthermore, in our case, the first-stage equation is of some independent interest.

\footnotetext{
${ }^{22}$ The weakness of the labor market in Houston, and in MSAs of the southwest region more generally, is probably attributable to the collapse of the price of oil during the 1980's.

${ }^{23}$ The $\mathrm{R}^{2}$ measures for IV equations reported in these tables are from the reduced-form equations, and therefore represent the fraction of the variation in the dependent variable explained by measured exogenous factors.
} 
The first-stage equation for the IV estimates in Table 3 (with standard errors in parentheses below coefficients) is as follows:

$$
\eta_{k}=-0.22+2.12 \hat{n}_{k} \quad R^{2}=0.21
$$

where $\eta_{k}$ reflects total local growth in hours of employment. The estimated coefficient on the instrument indicates that national demand shifts at the industry level have a multiplier effect of roughly 2 on employment at the local level. The equation also indicates that industry mix has a fair amount of explanatory power with regard to local employment changes, although, obviously, there is also a good deal of additional variation in the latter that is not accounted for by the former.

The results of Tables 3 and 4 show several clear patterns. Total demand growth within the MSA generally has significant positive effects on changes in both hourly wages and hours worked (per person) over the decade. The magnitudes of these effects are generally larger for younger than for older workers (especially on wages), larger for less-educated than for moreeducated workers, and larger for blacks than for whites (especially on hours worked). The overall pattern of results generally holds for females as well as for males. These results are largely consistent with others in the literature (e.g., Bartik, 1992; Freeman, 1991) to date, and indicate that falling overall labor demand contributes to higher inequality in the labor market.

Comparing the IV estimates to those of OLS, we find that the former are generally quite a bit larger than the latter, although the estimated sampling variability of the IV estimates is sufficiently large to imply that the differences are generally only marginally statistically significant. ${ }^{24}$ This is consistent with our notion that the latter estimates confound the effects of

\footnotetext{
${ }^{24}$ Differences between our OLS and IV estimates are somewhat larger than those found by Bartik and by Blanchard and Katz with comparable instruments. These differences might be due to larger supply shift biases in our analysis of a single cross-section of geographic areas rather than deviations from trend in time-series data.
} 
labor supply and demand shifts, leading to downward biases in the estimated effects of demand on market outcomes. Despite the fact that standard errors on the IV estimates are also substantially larger than on those from OLS, most of the differences described above in magnitudes of effects across demographic groups are statistically significant. ${ }^{25}$

Overall, these estimates imply that a $10 \%$ shift in demand away from an area would lead to nominal wage declines in all experience groups of $7 \%$ and $4 \%$ respectively among those with high school and college education. Among the least-experienced workers, the declines would be $11 \%$ and $6 \%$ respectively in the two education groups. Using data on price indices for the subset of our MSAs for which these data are available, we estimate that the decline in demand would lower price levels by roughly $2 \%$ in an area. ${ }^{26}$ Thus, much of the nominal wage declines noted above appear to reflect changes in real wages. The magnitudes of estimated effects on real wages of black workers in each category are even larger, and there are additional effects on hours worked, as well as on real wages for each group, that reinforce these findings.

With regard to labor supply adjustments, we find that changes in both population and total hours worked by group also are positively related to labor demand shifts. ${ }^{27}$ In general, population adjustments are larger among the more-educated and/or the least-experienced cohorts. The IV estimates of population adjustments are generally smaller than those from OLS, which is once again consistent with the idea that the latter confound the effects of demand shifts

${ }^{25}$ Differences in wage coefficients between the all experience and the 0-9 years categories are significant at the .05 level for both education groups. Differences in coefficients for hours worked between whites and blacks are significant at the .05 level among those with high school or less education for both experience groups and both genders; the difference in wage coefficients is significant only for males in the $0-9$ years category.

${ }^{26}$ Using price indices for 26 of our MSAs, we find elasticities of price levels with respect to local demand shifts of about .16 using OLS and about .26 using IV. These are comparable to Bartik's (1991) estimated long-run effects of about .2. Blanchard and Katz found somewhat larger effects that were dissipated after 10 years. One might worry that one should not use the same cost of living adjustments for the more- and less-educated, but work by Idson and Miller (1995) suggests that consumption bundles vary little by educational attainment.

${ }^{27}$ The coefficients from the total hours equations are simply the sums of those from the relevant equations for population adjustments and hours per person. 
and those of supply, in this case leading to upward biases in estimated effects. The IV estimates show quantitatively large and generally statistically significant differences in population adjustments across education and experience groups. The estimates imply that a $10 \%$ shift in demand away from an area would lead to declines in population for all experience groups of about $5 \%$ among college graduates and nothing among those with high school or less; in the youngest cohort, the corresponding declines would be roughly $11 \%$ and $6 \%$.

When comparing the population adjustments of whites with those of blacks within education, experience, and gender groups (Table 4), the picture is somewhat less clear. The estimates here generally indicate larger adjustments for whites only among less-educated and more-experienced males. In other cases, adjustments among blacks are comparable or even larger than among whites. ${ }^{28}$ Furthermore, at least some of the point estimates for blacks may be implausibly large, although they are estimated quite imprecisely. ${ }^{29}$

An alternative explanation for these results would stress the likelihood (explained on p. 3) that any given change in total labor market demand in an MSA implies larger effects on the group-specific labor demand facing blacks than whites. ${ }^{30}$ Thus, population adjustments to unit changes in total market demand that are comparable or greater among blacks than among whites might actually constitute smaller responses to unit changes in their respective group-specific demands.

\footnotetext{
${ }^{28}$ The larger effects for blacks are significant between females at both education levels and both experience levels, except that the one for less-educated and least-experienced women is marginal $(t=1,24)$. Between white and black males, the estimates are not significantly larger for blacks, except marginally among less-educated workers with 0-9 years experience $(t=1.36)$. The larger estimate for less-educated white males in all experience groups is also only marginally significant $(t=1.31)$.

${ }^{29}$ For instance, the estimates suggest that a $10 \%$ decline in local demand would generate declines in the populations of the youngest experience groups of $13 \%$ among less-educated black males, $17 \%$ among more-educated black males, and $19 \%$ among more-educated black females.

${ }^{30}$ This is also consistent with the generally larger effects of total market demand on the wages and employment of blacks than whites that we observe in Table 3.
} 
It is also of some interest to compare the nature of the supply adjustments made by the various populations -- that is, to what extent do these adjustments occur via a change in average hours per person and to what extent via population shifts. To provide evidence on this issue, we present an additional set of estimates for population adjustment in Table 5. These estimates are from regressions of population changes for a particular group on changes in total hours worked by that group (instead of the MSA overall), where the latter is once again instrumented by $\hat{n}_{k}{ }^{31}$. Since the change in the log of total hours worked is the sum of the changes in the logs of population changes and in hours per person, the regression will measure the shares of observed changes in total hours worked of that group accounted for by population adjustment (with the remainder accounted for by changes in hours per person). The IV estimates can be interpreted as measures of the extent to which exogenous demand shifts for a particular group result in population (as opposed to per person employment) adjustment. For the cases in which $\hat{\eta}_{k}$ has little impact on total hours (e.g., white women) the IV estimates will not be very meaningful. Such cases have been noted in Table 5 with a "*”.

The results of the table show that population adjustment generally accounts for more of the observed changes in total hours among the more-educated and/or younger workers, which is consistent with our earlier estimates. Indeed, the relative lack of population adjustment among older, less-educated workers is particularly striking. Within the less-educated groups, we now find that population adjustments for blacks account for smaller shares of adjustments to demand shifts than they do for whites. This is true among both males and females, and at all experience levels. In contrast, population adjustments among more educated blacks are roughly comparable

\footnotetext{
${ }^{31}$ These coefficients could be obtained by dividing the estimated IV effects of demand on population adjustment by those on total hours for any particular group in Table 3 or 4 .
} 
to those observed among their white counterparts.

These results are largely consistent with the fact noted earlier that gross migration rates are generally lower for blacks than for whites, even within education level. ${ }^{32}$ Together they suggest that supply responsiveness to labor demand shifts of a given magnitude is lower among blacks than whites, even after controlling for educational levels.

By how much might the differential wage response across skill groups to demand shocks contribute to the observed growth in wage inequality between them? The IV results from Table 3 suggest that a $10 \%$ shift in labor demand between areas would contribute roughly $2.7 \%$ to the difference in wages between the two groups in the declining areas. Using numbers from Table 2 , this estimate implies that our exogenous demand shift measure can account for roughly 20$25 \%$ of the difference between Boston and Detroit or $40 \%$ of the difference between New York and Detroit in terms of the growth in the college/high school wage differential. A visual sense of the explanatory power of our demand shift measure can be obtained from Figure 3, where we plot relative wages against predicted overall demand for the same set of MSAs that we use in Table 2.

More generally, the $R^{2} s$ reported in Table 3 suggest that our exogenous demand measure, $\hat{n}_{k}$, can explain 14 percent of the variation in relative wages. However, our calculations show that even using the large Census samples, there is a considerable amount of sampling error in our mean wage change measures. Adjusting for this measurement error boosts the $R^{2}$ to above 20

\footnotetext{
${ }^{32}$ For instance, in the 1975-1980 period, Census data show gross migration rates among white and black MSA residents was 0.17 and 0.09 respectively. Among high school drop-outs the corresponding rates were 0.10 and 0.07 ; among high school graduates they were 0.15 and 0.10 (U.S. Department of Commerce 1981). We found similar results using NLSY data. The NLSY data show $19.6 \%$ of young white male high school graduates, but only $13.0 \%$ of black make high-school graduates moving across metro areas between 1979 and 1988 (Bound and Holzer 1995).
} 
percent. ${ }^{33}$ Moreover, our exogenous demand measure presumably picks up only a component of demand. Thus, it is possible that demand shifts can explain a large fraction of the true variation in relative wages across the MSAs in our sample. However, the fact that many of the MSAs that experience large relative wage changes were also those that experienced large increases in their immigrant population during the 1980s (e.g., Miami) at least suggests that immigration may have also played a role (Topel 1994; Jaeger 1996).

\section{Effect of Supply and Demand Factors on Relative Wages}

The reduced-form regression results presented above show that local demand shifts have larger effects on labor market outcomes among less-educated workers, while supply adjustments to these demand shifts are lower among these groups. In fact, the estimated different supply adjustments are large enough to at least potentially explain the entire differential impact of local demand shocks on the wages of college- and high school-educated workers. The IV estimates reported in Table 3 suggest that a 10 percent demand-induced drop in employment will lower the relative supply of college graduates to the local labor market by 3.6 percent, while raising their relative wages by 2.7 percent. For such relative supply adjustments to be able to fully explain the relative wage adjustments, the elasticity of substitution between high school- and collegeeducated labor would have to be no greater than $11 / 3$, which is well within the range suggested by conventional wisdom.

To more directly estimate the effects of relative supply adjustments on relative wages between skill groups, we present estimates from regressions of the latter on the former across

\footnotetext{
${ }^{33}$ Comparing the (weighted) average of estimated variances of the first-stage $\beta_{k}$ s to the variance of the $\beta_{k} s$ themselves, we calculate that $37 \%$ of the apparent variation in relative wages is "noise".
} 
MSAs (Table 6). These equations also include controls for relative demand shifts between more- and less-educated workers. These measures are designed to capture the notion that changing industrial structure of employment might shift demand across groups even if total labor demand in an area remains unchanged (for reasons described in Section $\mathrm{I}$ ). ${ }^{34}$

Differences in changes in logs of wages between workers with college or more and those with high school or less education are the dependent variables here, while differences in changes in supply and demand measures between these groups are the independent variables. The supply measures used here are total hours worked by each group. Because of the endogeneity of supply shifts, we instrument them with $\hat{n}_{k}$. This supply measure should therefore capture the differences across groups in the extent of supply responsiveness to demand shifts that we observed above, and should enable us to estimate the effect of these differences on relative wages across groups.

To proxy for changes in relative demand we have used a number of different measures, all based on changes in the industrial structure of an area. For our first measure we use a variant of the fixed-coefficient measure of demand often used in the literature (e.g., Katz and Murphy, 1992). We calculate the demand shift in favor of group $i$ in area $k$ as

$$
\hat{D}_{i k}=\sum_{j} Y_{i j k} \eta_{j k^{\prime}}
$$

where $i$ indexes skill groups, $j$ industries, and $k$ metro areas. As before $Y_{i j k}$ represents the share of the $i_{t h}$ demographic group in the $j_{t h}$ industry in the $k_{t h}$ metro area, while $n_{j k}$

\footnotetext{
${ }^{34}$ We have no explicit measures of rates of capital inflows or technological change across metropolitan areas. Correlations between these unobserved factors and our relative supply and demand measures are potential sources of bias in our estimated effects of the latter, though the signs of these biases are not clear $a$ priori.
} 
represents the growth rate of industry $j$ in area $k$. Thus, we now use industry shares of local employment for specific skill groups, which weight local (rather than national) industry employment growth. We use the difference between the $\hat{D}_{i k}$ for workers with college or more education versus those with high school or less as our relative demand measure.

Alternative measures of relative demand are based exclusively on two industries in which many less-educated workers have traditionally been employed, often earning a premium in wages - i.e., manufacturing and construction. Indeed, declining employment in manufacturing has specifically been linked to declining employment levels among blacks and declining earnings among the less-educated more generally in several previous studies (noted above). In some equations below, we therefore use changes in the shares of employment that are accounted for by one or both of these industries between 1979 and 1989 in place of the relative demand indices.

The results reported in Table 6 confirm expectations that relative supply responses to exogenous demand shocks have large effects on relative wages. The inclusion of the demand shift measures tends to mute but not eliminate the estimated effect of relative supply. This suggests that, while changes in the relative supply may be an important factor affecting the change in relative wages, demand factors may also play a role. Relative demand shifts have the anticipated positive effects and are at least marginally significant. When the change in the share of employment in manufacturing alone is used in place of the relative demand measure, it generates the anticipated negative effect on the relative wage difference, although its effect is not significant. The inclusion of construction along with manufacturing generates much stronger effects.

Unlike Topel (1993, 1994), we find effects of relative demand but not supply in the OLS versions of these equations. However, when we performed our analysis at the division level 
(defining wage outcomes at the division level in a way exactly analogous to the way we defined them at the MSA level), we find a strong correlation between wage and supply changes. At the division level, a regression of the change in the college/high school wage differential on the change in relative hours gives a coefficient on the relative supply measure of $-.52(.16)$, $R^{2}=.59$. One interpretation of this difference is that labor supply shifts are more exogenous with respect to larger geographic units. ${ }^{35}$

\section{Conclusion}

In this paper we explore the effects of changes in the economy's geographic, industrial and occupational structure on the earnings and employment of white and black men and women during the 1980s. We also explore how population adjustments (primarily through migration across metropolitan areas) vary across these groups in response to these economic changes.

The results show that earnings and employment deteriorated the most for less-educated and/or black males in the 1980s. These effects occurred in almost all MSAs nationwide, although they were most severe in the industrial areas of the Midwest. Overall labor demand shifts had relatively large effects on the earnings and employment on these groups in these areas during that time period.

We also found evidence of supply effects on local labor market outcomes, working through population adjustments in response to shifts in labor demand. However, older and lesseducated workers have the most limited short-run labor supply adjustments to these demand shifts in terms of intermetropolitan migration; and there was some evidence of lower response

\footnotetext{
${ }^{35}$ A similar point was made by Borjas, Freeman, and Katz (1996) when considering results on the impact of immigration on wages.
} 
among blacks as well, even within education group. These limited adjustments appear to

contribute to the relatively greater deterioration of their earnings in declining areas during the 1980s.

There are a number of plausible reasons for why these groups might migrate less in response to demand shifts: less information about alternative labor market opportunities in other areas; fewer social contacts in growing areas; or lower assets with which to finance the fixed costs of a move. ${ }^{36}$ Although there have been historical periods in which less-educated workers in the U.S. migrated in very large numbers (such as the south-to-north migration of blacks between the 1920 s and the 1960 s), it may take fairly dramatic shifts in regional economic conditions to overcome the costs and barriers faced by potential migrants across these areas. ${ }^{37}$ Regardless of their causes, the implications of these shifts for employment and earnings differences among groups may be quite substantial.

We must note several caveats in presenting these findings. Given the nature of our data, we could only analyze the part of labor demand shifts that are between sectors (defined by twodigit industries) rather than within them. Our ability to distinguish changes in total labor demand in an MSA from shifts in relative demand across different groups was also limited, given the

\footnotetext{
${ }^{36}$ For instance, Greenwood (1975) notes that college-educated migrants are much more likely to have a job lined up prior to a move than are migrants with less education, which is consistent with the idea that the former are better informed about job opportunities in other areas because their labor markets are often regional or national in scope. Lansing and Mueller (1967) note that college-educated migrants report a greater role for economic factors in their decisions to move than do the less-educated; and that blacks cite family/community reasons for moving or not moving more frequently than do whites. Consistent with this, Stack (1996) presents a description of blacks returning to families and communities in economically depressed areas of the rural South after having migrated northward in earlier periods (though Frey (1995) also documents the return migration of blacks to metropolitan areas in the South, where economic conditions are presumably more favorable). For evidence on the importance of informal networks among both whites and blacks when searching for jobs, see Holzer (1987); and for evidence of much lower assets among blacks than whites, see Blau and Graham (1990). Relative immigration rates across skill and racial groups might also be affected by relative rates of marriage and differences in the presence of dual-earner families across these groups.
}

${ }^{37}$ See Uhlenberg (1973) and Trotter (1994) for more discussion of the role of economic and social forces in generating the out-migration of Southern blacks in the $1920 \mathrm{~s}$, and the relative lack of out-migration before that time. 
fairly small number of MSAs for which we had sufficient numbers of blacks and whites within education and experience groups.

Since we are analyzing data on population adjustments over a 10 -year period we cannot distinguish between short- and long-run responses to demand shifts. Nor can we distinguish between expected and unexpected shifts. Nevertheless, the results presented here strongly suggest that both demand shifts and supply adjustments contributed to the labor market problems of less-educated and black workers in declining areas in recent years. Further research on why the adjustment mechanisms are used more or less frequently by different groups (i.e., whether the differences are caused by information, financial costs, etc.), and on the potential effects of various policy options, should be high on our agendas. 


\section{Bibliography}

Amemiya, Takeshi. "A Note on a Random Coefficients Model." International Economics Review 19 (1978): 793-96.

Acs, Gregory and Danziger, Sheldon. "Educational Attainment, Industrial Structure, and Earnings: 1973-87." Journal of Human Resources 28 (1993): 618-48.

Bartik, Timothy. "Economic Development and Black Economic Success." Report to the Economic Development Administration, U.S. Department of Commerce, 1992.

Bartik, Timothy. Who Benefits from State and Local Economic Development Policies? W.E. Upjohn Institute, 1991.

Bartik, Timothy. "Who Benefits from Local Job Growth: Migrants or the Original Residents?" Regional Studies 27 (1993): 297-311.

Blanchard, Olivier and Katz, Lawrence. "Regional Evolutions." Brookings Papers on Economic Activity (1992): 1-61.

Blau, Francine D., and Graham, John W. "Black-White Differences in Wealth and Asset Composition." Quarterly Journal of Economics 105 (May 1990): 321-38.

Bluestone, Barry, Mary Stevenson, and Tilly, Christopher. "An Assessment of the Impact of Deindustrialization and Spatial Mismatch on the Labor Market Outcomes of Young White, Black and Latino Men and Women Who Have Limited Schooling." Report to the National Science Foundation, 1992.

Bound, John and Freeman, Richard. "What Went Wrong? The Erosion of Relative Earnings and Employment Among Young Black Men in the 1980's." Quarterly Journal of Economics 107 (Feb. 1992): 201-32.

Bound, John and Holzer, Harry J. "Industrial Structure, Skill Levels, and the Labor Market for White and Black Males." Review of Economics and Statistics 75 (Aug. 1993): 387-396.

Bound, John and Holzer, Harry J. "Structural Changes, Employment Outcomes, and Populations Adjustments, 1980-1990." Institute for the Research on Poverty Discussion Paper \#105795 Feb. 1995.

Bound, John, Jaeger, David A., and Baker, Regina M. "Problems with Instrumental Variables Estimation when the Correlation Between the Instruments and the Endogenous Explanatory Variables is Weak," Journal of the American Statistical Assocation, 90 (June 1995): 443-450. 
Bound, John and Johnson, George. "Changes in the Structure of Wages: An Evaluation of Alternative Hypotheses." American Economic Review 82 (June 1992): 371-92.

Borjas, George J., Freeman, Richard B. and Katz, Lawrence F. "Searching for the Effect of Immigration on the Labor Market." American Economic Review 86 (May 1996): 246251.

Bradbury, Katharine L., Downs, Anthony and Small, Kenneth A. Urban Decline and the Future of American Cities. Washington, D.C.: The Brookings Institution, 1982.

Coulsen, Edward and Rushen, Steven. "Sources of Fluctuations in the Boston Economy." Journal of Urban Economics 38 (Feb. 1995): 74-93.

Dickens, William and Katz, Lawrence. Industry Wage Differences and Industry Characteristics." In K. Lang and J. Leonard eds., Unemployment and the Structure of Labor Markets. London: Basil Blackwell, 1987.

Freeman, Richard. "Economic Determinants of Individual and Geographic Variation in Employment Outcomes of Youth." In R. Freeman and D. Wise, eds., The Youth Labor Market Problem. Chicago: University of Chicago Press, 1982.

Freeman, Richard. "Employment and Earnings of Disadvantaged Young Men in a Labor Shortage Economy." In C. Jencks and P. Peterson eds., The Urban Underclass. Washington, DC: Brookings Institution, 1991.

Freeman, Richard B. "Manpower Requirements and Substitution Analysis of Labor Skills: A Synthesis", in Ronald Ehrenberg ed., Research in Labor Economics 1 (1977): 151-184.

Frey, William. "The New Geography of Population Shifts." In R. Farley ed., State of the Union, Vol. 2. New York: Russell Sage Foundation, 1995.

Greenwood, Michael. "Research in Internal Migration in the U.S. A Survey." Journal of Economic Literature 13 (June 1975): 397-433.

Hamermesh, Daniel. Labor Demand. Princeton: Princeton University Press, 1993.

Hauser, Robert. "Trends in College Entry Among Whites, Blacks, and Hispanics." In C. Clotfelter and M. Rothschild eds., Studies of Supply and Demand for Higher Education. Chicago: University of Chicago Press, 1993.

Holzer, Harry J. "Informal Job Search and Black Youth Unemployment." American Economic Review 77 (June 1987): 446-52.

Holzer, Harry J. "The Spatial Mismatch Hypothesis: What Has the Evidence Shown?" Urban Studies 28 (Feb. 1991): 105-22. 
Holzer, Harry J. and Wayne Vroman. "Mismatches and Urban Labor Markets." In G. Peterson and W. Vroman eds., Urban Labor Markets and Job Opportunities. Washington, D.C.: Urban Institute, 1992.

Idson, Todd and Cynthia Miller. "The Implications of Demographic-Specific Inflation Rates for Trends in Real Educational Wage Differentials." Manuscript, Columbia University, 1995.

Jaeger, David A. "Regional and Local Area Impacts of Immigration on Natives Wages." Manuscript, Bureau of Labor Statistics. 1996.

Johnson, James and Melvin Oliver. "Structural Changes in the U.S. Economy and Black Male Joblessness: A Reassessment." in G. Peterson and W. Vroman eds., Urban Labor Markets and Job Opportunities. Washington, D.C.: Urban Institute, 1992.

Jones, Ronald W. "The Structure of General Equilibrium Models." Journal of Political Economy 73 (Dec. 1965): 557-72.

Juhn, Chinhui. "Wage Inequality and Industrial Change: Evidence from Five Decades." NBER Working Paper 4684, 1994.

Kane, Thomas. "College Entry by Blacks Since 1970: The Role of College Costs, Family Background, and the Returns to Education." Journal of Political Economy 102 (Oct. 1994): 878-911.

Karoly, Lynn and Jacob Klerman. "Demographics, Sectoral Change, and Changing Relative Wages: A Regional Approach." Rand Corporation DRU-795-NICHD, 1994.

Kasarda, John. "Urban Industrial Transition and the Underclass." Annals of the American Academy of Political and Social Science 501 (Jan. 1989): 26-47.

Katz, Lawrence and Kevin Murphy. "Changes in Relative Wages, 1963-87: Supply and Demand Factors." Quarterly Journal of Economics 107 (Feb. 1992): 35-78.

Krueger, Alan and Lawrence Summers. "Reflections on the Inter-Industry Wage Structure." In

K. Lang and J. Leonard (eds.), Unemployment and the Structure of Labor Markets. London: Basil Blackwell, 1987.

Krugman, Paul. Geography and Trade, Cambridge: MIT press, 1991 .

Lansing, John and Eva Mueller. The Geographic Mobility of Labor. Institute for Social Research, University of Michigan, 1967.

Levy, Frank and Murnane, Richard. "U.S. Earnings Levels and Earnings Inequality: A Review of 
Recent Trends and Proposed Explanations." Journal of Economic Literature 30 (Sept. 1992): 1333-81.

Long, Larry. Migration and Residential Mobility in the United States. New York: Russell Sage Foundation, 1988.

MacKinnon, J.G. and White, H. "Some Heteroskedasticity-Consistent Covariance Matrix Estimators with Improved Finite Sample Properties." Journal of Econometrics 29 (Sept. 1985): 305-25.

Nelson, C. R., and Startz, R. "Some Further Results on the Exact Small-Sample Properties of the Instrumental Variable Estimator." Econometrica 58 (July, 1990a): 967-76.

Nelson, C.R., and R. Startz. "The Distribution of the Instrumental Variable Estimator and its $t$ Ratio when the Instrument is a Poor One." Journal of Business 63 Part 2 (Jan. 1990b): S125-S140.

Schwartz, Aba. "Interpreting the Effects of Distance on Migration." Journal of Political Economy 81 (Sept.-Oct., 1973): 1153-69.

Stack, Carol. Call to Home: African-Americans Reclaim the Rural South. New York: Basic Books, 1996.

Terkla, David and Doeringer, Peter. "Explaining Variations in Employment Growth: Structural and Cyclical Change among States and Local Areas." Journal of Urban Economics, 29 (May 1991): 329-48.

Topel, Robert. "Local Labor Markets." Journal of Political Economy 94 (June 1986): S111S143.

Topel, Robert. "Wage Inequality and Regional Labor Market Performance in the United States." Manuscript, University of Chicago, 1993.

Topel, Robert. "Regional Labor Markets and the Determinants of Wage Inequality." American Economic Review 84 (May 1994): 17-22.

Trotter, Joe ed.. The Great Migration in Historical Perspective. Bloomington: Indiana University Press, 1991.

Uhlenberg, Peter. "Noneconomic Determinants of Nonmigration: Sociological Considerations for Migration Theory." Rural Sociology 38 (Fall 1973): 296-311.

U.S. Department of Commerce, Bureau of the Census. "Geographical Mobility, March 1975March 1980." Current Population Reports Series P-20, No. 368, 1981. 
White, Halbert. "Heteroskedasticity-Consistent Covariance Matrix Estimation and a Direct Test for Heteroskedasticity." Econometrica 48 (May, 1980): 817-38.

White, Halbert." Instrumental Variables Regression with Independent Observations." Econometrica 50 (March, 1982): 483-499. 
Figure 1: Labor Market Adjustments to an Adverse Demand Shock

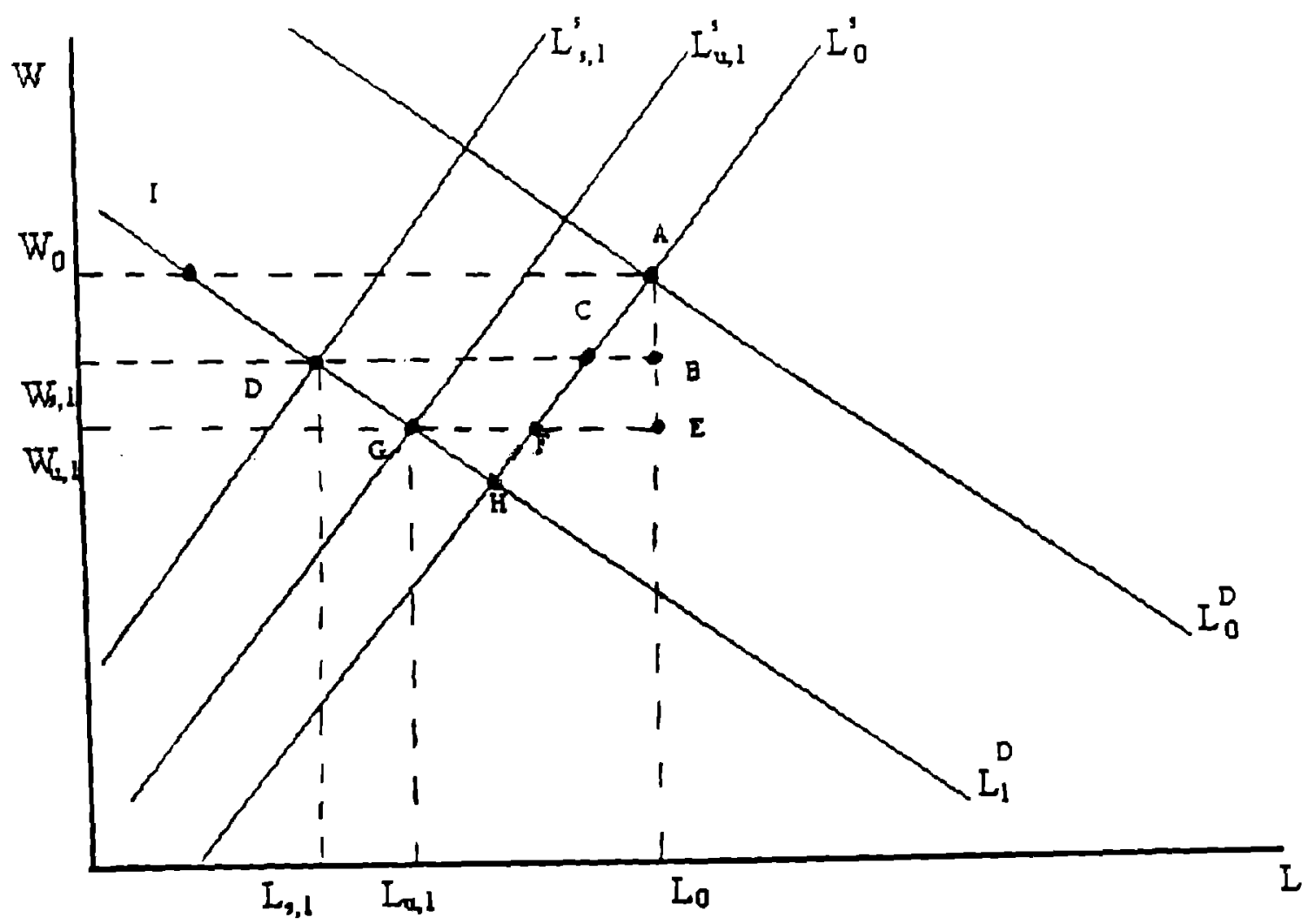

NOTE: "U" and "S" refer to unskilled and skilled workers respectively 
Figure 2: Real Wage Growth for High School and College Graduates

Metro Areas with Populations over 2.5 Million in 1990

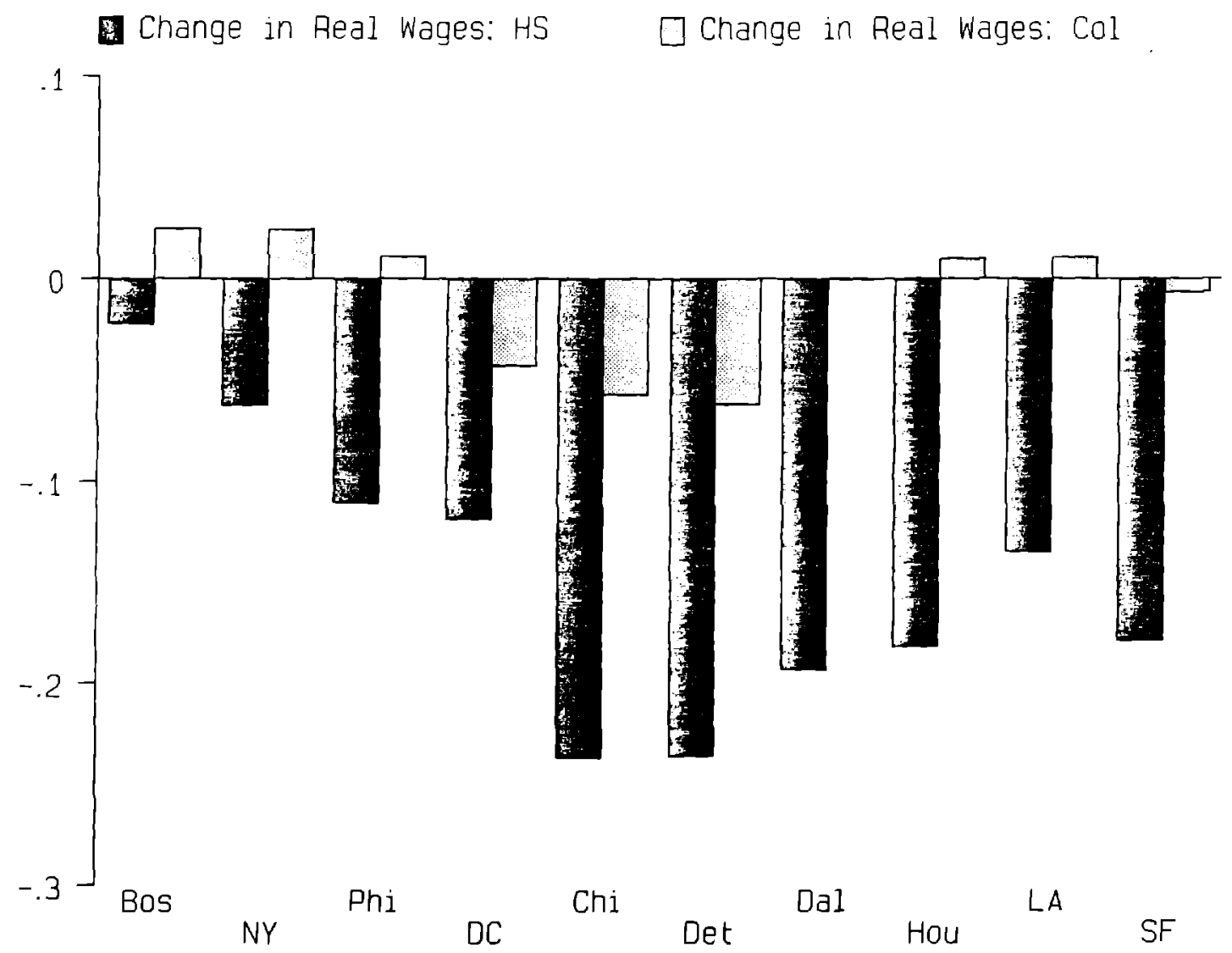


Figure 3: Effect of Demand on the Wages of College Relative to High School Graduates Metro Areas with Populations over One Million in 1990

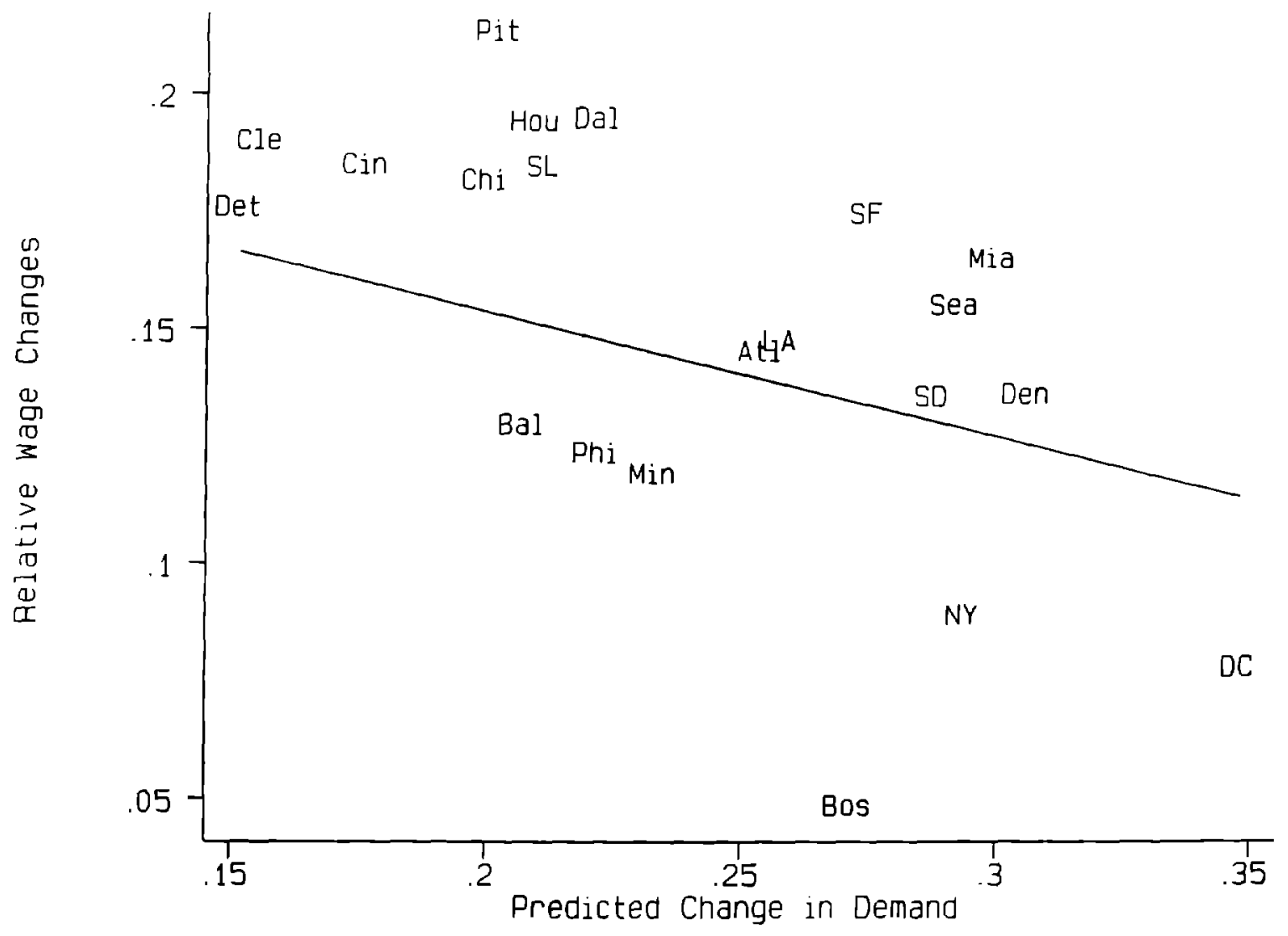


Table 1

Labor Market Outcomes

by Demographic Group: 1979-89

(Means and Standard Deviations)

High School or Less

College or More

Wages Hours Pop. T, Hrs.

Wages Hours Pop T. Hrs.

All Exp. Groups

$\begin{array}{llll}-.14 & .00 & -.42 & -.41\end{array}$

$(.09) \quad(.04) \quad(.13) \quad(.14)$

$\begin{array}{llll}.01 & .04 & -.08 & -.04\end{array}$

$(.06) \quad(.02) \quad(.14) \quad(.14)$

0-9 Years Exp.

$\begin{array}{lccc}-.12 & .00 & -.38 & -.38 \\ (.13) & (.05) & (.15) & (.18)\end{array}$

$\begin{array}{llll}.02 & .04 & .00 & .04\end{array}$

$(.08) \quad(.02) \quad(.19) \quad(.20)$

All Experience Groups:

White Males

$\begin{array}{llll}-.13 & .01 & -.43 & -.43\end{array}$

$\begin{array}{llll}.01 & .04 & -.08 & -.04\end{array}$

$\begin{array}{lll}(.10) \quad(.03) \quad(.13) \quad(.14) & \end{array}$

$(.06) \quad(.02) \quad(.14) \quad(.14)$

Black Males

$\begin{array}{llll}-.15 & -.02 & -.15 & -.17\end{array}$

$\begin{array}{llll}.01 & .03 & .04 & .07\end{array}$

$\begin{array}{llll}(.11) & (.09) \quad(.16) \quad(.20)\end{array}$

$(.11) \quad(.06) \quad(.21) \quad(.23)$

$\begin{array}{lllll}\text { White Females } & -.02 & .08 & -.59 & -.51\end{array}$

$\begin{array}{llll}.12 & .19 & .05 & .24\end{array}$

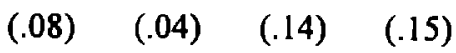

$\begin{array}{llll}(.07) & (.03) \quad(.14) \quad(.13)\end{array}$

$\begin{array}{lllll}\text { Black Females } & -.11 & -.02 & -.33 & -.35\end{array}$

$\begin{array}{llll}.03 & .17 & .10 & .27\end{array}$

$(.09) \quad(.09) \quad(.15) \quad(.17)$

$(.10) \quad(.07) \quad(.18) \quad(.19)$

0-9 Years Experience:

White Males

$\begin{array}{llll}-.10 & .01 & -.40 & -.39\end{array}$

$\begin{array}{llll}.02 & .05 & .03 & .08\end{array}$

$(.15) \quad(.04) \quad(.16) \quad(.18)$

$(.08) \quad(.03) \quad(.18) \quad(.19)$

Black Males

$\begin{array}{llll}-.13 & -.04 & -.08 & -.12\end{array}$

$\begin{array}{llll}-.04 & .07 & .07 & .15\end{array}$

$(.18) \quad(.14) \quad(.20) \quad(.28)$

(.15)

(.09) (.35)

(.35)

$\begin{array}{lllll}\text { White Females } & -.01 & .07 & -.57 & -.50 \\ & (.11) & (.05) & (.15) & (.17)\end{array}$

$\begin{array}{cccc}.12 & .19 & .14 & .32 \\ (.08) & (.03) & (.17) & (.17)\end{array}$

$\begin{array}{lllll}\text { Black Females } \quad-.08 & .03 & -.26 & -.23\end{array}$

$\begin{array}{llll}(.16) \quad(.16) \quad(.16) & (.24)\end{array}$

$\begin{array}{llll}.04 & .16 & .11 & .26\end{array}$

$\begin{array}{llll}(.13) & (.09) \quad(.28) \quad(.30)\end{array}$

Sample: 132 largest MSAs for the top two rows, 87 MSAs with the largest Black populations for the rest.

Note: Observations are weighted by the average of 1980 and 1990 population shares. All variables are measured as changes in logs, 1979 - 89. "T. Hrs." represents Total Hours, which is the product of population ("Pop.") and the average hours per person ("Hours"). Calculations are based on the nonenrolled and noninstitutionalized civilian populations aged 16 and over. Nominal wage changes have been deflated by the log of the change in the CPI-U-X1 index between 1979-89. 


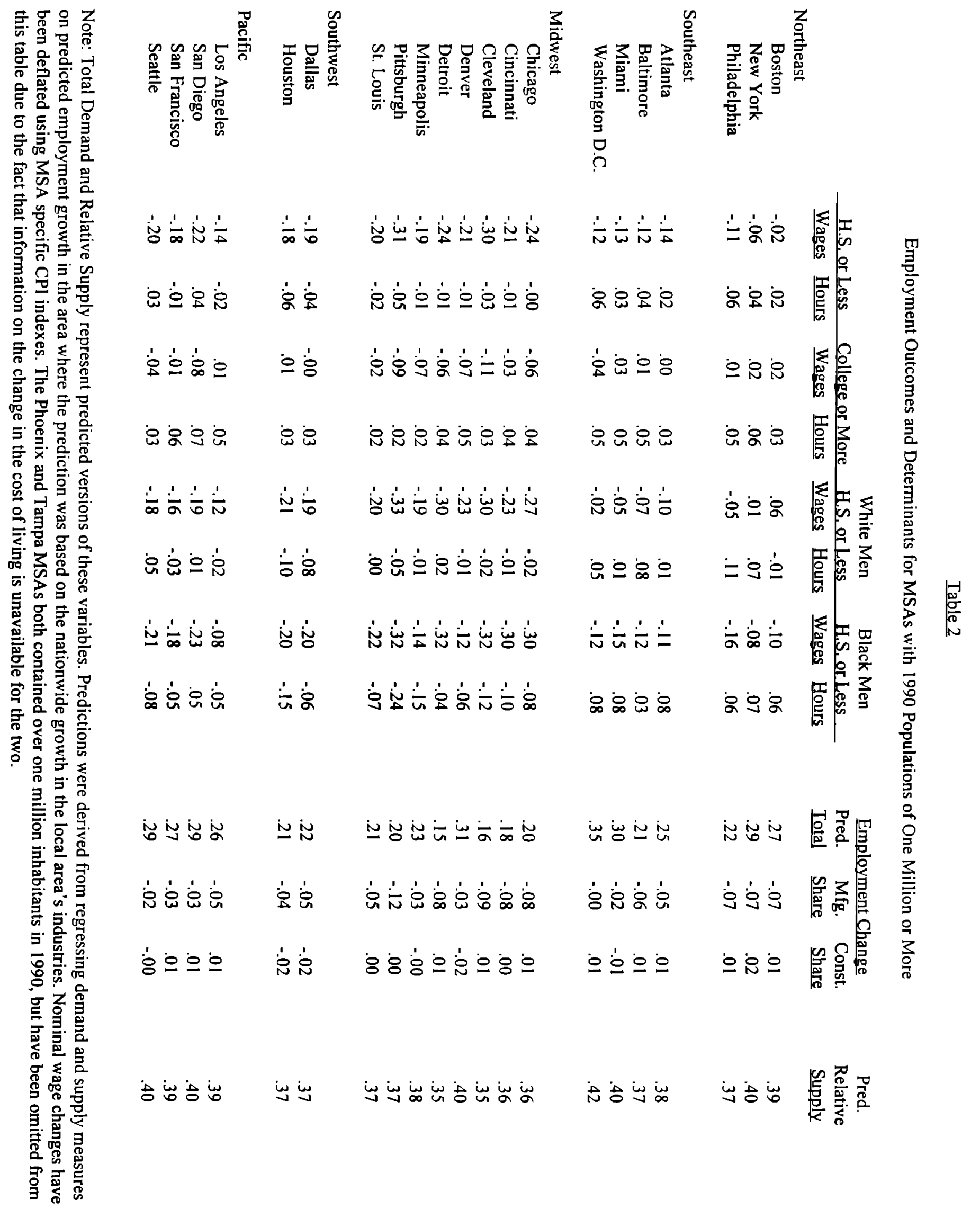


Table 3

Effects of Demand on Outcomes:

By Education and Experience

(Eicher-White Standard Errors in Parentheses)

OLS

Wages Hours Pop T. Hrs
IV

Wages Hours Pop T.Hrs.

All Experince Groups:

\begin{tabular}{|c|c|c|c|c|c|c|c|c|}
\hline College & $\begin{array}{l}.16 \\
(.04)\end{array}$ & $\begin{array}{c}.03 \\
(.01)\end{array}$ & $\begin{array}{c}.83 \\
(.07)\end{array}$ & $\begin{array}{c}.86 \\
(.06)\end{array}$ & $\begin{array}{c}.42 \\
(.19)\end{array}$ & $\begin{array}{l}.12 \\
(.05)\end{array}$ & $\begin{array}{c}.44 \\
(.14)\end{array}$ & $\begin{array}{c}.56 \\
(.11)\end{array}$ \\
\hline $\mathrm{R}^{2}$ & .13 & .07 & .68 & .71 & .20 & 19 & .04 & .06 \\
\hline High School & $\begin{array}{c}.20 \\
(.06)\end{array}$ & $\begin{array}{c}.09 \\
(.02)\end{array}$ & $\begin{array}{c}.74 \\
(.06)\end{array}$ & $\begin{array}{c}.82 \\
(.06)\end{array}$ & $\begin{array}{c}.69 \\
(.31)\end{array}$ & $\begin{array}{c}.24 \\
(.10)\end{array}$ & $\begin{array}{l}-.05 \\
(.29)\end{array}$ & $\begin{array}{c}.20 \\
(.22)\end{array}$ \\
\hline $\mathrm{R}^{2}$ & .09 & .11 & .57 & .62 & .24 & .18 & .00 & .01 \\
\hline College - H.S. & $\begin{array}{l}-.04 \\
(.03)\end{array}$ & $\begin{array}{l}-.05 \\
(.02)\end{array}$ & $\begin{array}{c}.09 \\
(.06)\end{array}$ & $\begin{array}{c}.04 \\
(.06)\end{array}$ & $\begin{array}{l}-.27 \\
(.14)\end{array}$ & $\begin{array}{l}-.13 \\
(.06)\end{array}$ & $\begin{array}{c}.49 \\
(.23)\end{array}$ & $\begin{array}{c}.36 \\
(.21)\end{array}$ \\
\hline $\mathbf{R}^{2}$ & .02 & .05 & .02 & .00 & .14 & .06 & .10 & .05 \\
\hline
\end{tabular}

\section{0 - 9 Years Experience:}

\begin{tabular}{|c|c|c|c|c|c|c|c|c|}
\hline College & $\begin{array}{c}.18 \\
(.05)\end{array}$ & $\begin{array}{c}.01 \\
(.02)\end{array}$ & $\begin{array}{c}.95 \\
(.09)\end{array}$ & $\begin{array}{c}.97 \\
(.09)\end{array}$ & $\begin{array}{c}.58 \\
(.24)\end{array}$ & $\begin{array}{l}.10 \\
(.07)\end{array}$ & $\begin{array}{l}1.14 \\
(.29)\end{array}$ & $\begin{array}{l}1.24 \\
(.35)\end{array}$ \\
\hline $\mathrm{R}^{2}$ & .11 & .01 & .46 & .44 & .24 & .06 & .14 & .15 \\
\hline High School & $\begin{array}{c}.32 \\
(.09)\end{array}$ & $\begin{array}{c}.04 \\
(.04)\end{array}$ & $\begin{array}{c}.88 \\
(.06)\end{array}$ & $\begin{array}{c}.92 \\
(.08)\end{array}$ & $\begin{array}{l}1.11 \\
(.45)\end{array}$ & $\begin{array}{c}.22 \\
(.15)\end{array}$ & $\begin{array}{l}.60 \\
(.19)\end{array}$ & $\begin{array}{c}.82 \\
(.28)\end{array}$ \\
\hline $\mathrm{R}^{2}$ & .11 & .01 & .62 & .51 & .29 & .06 & .06 & .08 \\
\hline College - H.S. & $\begin{array}{l}-.13 \\
(.05)\end{array}$ & $\begin{array}{l}-.03 \\
(.03)\end{array}$ & $\begin{array}{c}.07 \\
(.10)\end{array}$ & $\begin{array}{c}.04 \\
(.10)\end{array}$ & $\begin{array}{l}-.53 \\
(.23)\end{array}$ & $\begin{array}{l}-.12 \\
(.11)\end{array}$ & $\begin{array}{c}.54 \\
(.30)\end{array}$ & $\begin{array}{c}.42 \\
(.27)\end{array}$ \\
\hline $\mathrm{R}^{2}$ & .06 & .01 & .00 & .00 & .20 & .02 & .05 & .03 \\
\hline
\end{tabular}

Sample: 132 largest MSAs.

Note: All regressions are population weighted. See text for details. The $\mathrm{R}^{2}$ measures for IV estimates are from reduced-form equations where the dependent variables were regressed directly on the instrument. The instrument used for IV estimates involves employment growth in the MSA as predicted from the national growth of the local area's industries. For details, see the text. The first stage $\mathrm{R}^{2}$ for these estimates is 0.21 , while the first stage $F$ is 34.1 . 
Table 4

Effects of Demand on Outcomes:

By Education, Experience, Race and Gender Instrumental Variable Estimates

(Eicher-White Standard Errors in Parentheses)

High School or Less

College or More

Wages Hours Pop $\underline{\text { T. Hrs }}$

Wages Hours Pop. T.Hrs.

All Experience Groups:

\begin{tabular}{|c|c|c|c|c|c|c|c|c|}
\hline $\begin{array}{l}\text { All Race/Sex } \\
\text { Populations }\end{array}$ & $\begin{array}{l}.79 \\
(.37)\end{array}$ & $\begin{array}{l}.25 \\
(.11)\end{array}$ & $\begin{array}{l}.09 \\
(.30)\end{array}$ & $\begin{array}{c}.34 \\
(.22)\end{array}$ & $\begin{array}{l}.46 \\
(.22)\end{array}$ & $\begin{array}{l}.11 \\
(.05)\end{array}$ & $\begin{array}{l}.41 \\
(.17)\end{array}$ & $\begin{array}{l}.52 \\
(.14)\end{array}$ \\
\hline Whites Males & $\begin{array}{l}.82 \\
(.44)\end{array}$ & $\begin{array}{l}.22 \\
(.07)\end{array}$ & $\begin{array}{r}-.05 \\
(.33)\end{array}$ & $\begin{array}{l}.17 \\
(.29)\end{array}$ & $\begin{array}{l}.38 \\
(.20)\end{array}$ & $\begin{array}{l}.16 \\
(.07)\end{array}$ & $\begin{array}{l}.34 \\
(.20)\end{array}$ & $\begin{array}{l}.50 \\
(.16)\end{array}$ \\
\hline White Females & $\begin{array}{l}.83 \\
(.34)\end{array}$ & $\begin{array}{l}.13 \\
(.10)\end{array}$ & $\begin{array}{l}-.34 \\
(.40)\end{array}$ & $\begin{array}{l}-.21 \\
(.35)\end{array}$ & $\begin{array}{c}.64 \\
(.27)\end{array}$ & $\begin{array}{l}.02 \\
(.06)\end{array}$ & $\begin{array}{l}.06 \\
(.28)\end{array}$ & $\begin{array}{l}.08 \\
(.25)\end{array}$ \\
\hline Black Males & $\begin{array}{l}.98 \\
(.40)\end{array}$ & $\begin{array}{c}.62 \\
(.30)\end{array}$ & $\begin{array}{l}.50 \\
(.25)\end{array}$ & $\begin{array}{l}1.12 \\
(.38)\end{array}$ & $\begin{array}{l}.72 \\
(.34)\end{array}$ & $\begin{array}{l}.05 \\
(.10)\end{array}$ & $\begin{array}{l}1.25 \\
(.39)\end{array}$ & $\begin{array}{l}1.30 \\
(.40)\end{array}$ \\
\hline Black Females & $\begin{array}{c}.73 \\
(.28)\end{array}$ & $\begin{array}{c}.61 \\
(.32)\end{array}$ & $\begin{array}{r}.24 \\
(.26)\end{array}$ & $\begin{array}{r}.85 \\
(.32)\end{array}$ & $\begin{array}{l}.54 \\
(.35)\end{array}$ & $\begin{array}{c}.20 \\
(.17)\end{array}$ & $\begin{array}{l}1.18 \\
(.44)\end{array}$ & $\begin{array}{l}1.39 \\
(.52)\end{array}$ \\
\hline
\end{tabular}

0-9 Years Experience:

\begin{tabular}{|c|c|c|c|c|c|c|c|c|}
\hline $\begin{array}{l}\text { All Race/Sex } \\
\text { Populations }\end{array}$ & $\begin{array}{l}1.24 \\
(.53)\end{array}$ & $\begin{array}{l}.21 \\
(.17)\end{array}$ & $\begin{array}{l}.84 \\
(.20)\end{array}$ & $\begin{array}{l}1.04 \\
(.33)\end{array}$ & $\begin{array}{c}.63 \\
(.29)\end{array}$ & $\begin{array}{l}.09 \\
(.08)\end{array}$ & $\begin{array}{l}1.04 \\
(.28)\end{array}$ & $\begin{array}{l}1.13 \\
(.34)\end{array}$ \\
\hline White Males & $\begin{array}{l}1.39 \\
(.66)\end{array}$ & $\begin{array}{l}.12 \\
(.09)\end{array}$ & $\begin{array}{l}.73 \\
(.26)\end{array}$ & $\begin{array}{l}.86 \\
(.32)\end{array}$ & $\begin{array}{l}.58 \\
(.29)\end{array}$ & $\begin{array}{l}.18 \\
(.10)\end{array}$ & $\begin{array}{l}1.08 \\
(.30)\end{array}$ & $\begin{array}{l}1.26 \\
(.37)\end{array}$ \\
\hline White Females & $\begin{array}{l}1.08 \\
(.44)\end{array}$ & $\begin{array}{c}.03 \\
(.10)\end{array}$ & $\begin{array}{l}.37 \\
(.25)\end{array}$ & $\begin{array}{l}.41 \\
(.26)\end{array}$ & $\begin{array}{c}.68 \\
(.29)\end{array}$ & $\begin{array}{l}-.02 \\
(.08)\end{array}$ & $\begin{array}{l}.54 \\
(.21)\end{array}$ & $\begin{array}{l}.52 \\
(.24)\end{array}$ \\
\hline Black Males & $\begin{array}{l}1.86 \\
(.67)\end{array}$ & $\begin{array}{c}.66 \\
(.38)\end{array}$ & $\begin{array}{l}1.32 \\
(.56)\end{array}$ & $\begin{array}{l}1.97 \\
(.88)\end{array}$ & $\begin{array}{c}.83 \\
(.40)\end{array}$ & $\begin{array}{l}.26 \\
(.13)\end{array}$ & $\begin{array}{l}1.64 \\
(.91)\end{array}$ & $\begin{array}{l}1.90 \\
(.93)\end{array}$ \\
\hline Black Females & $\begin{array}{l}1.27 \\
(.47)\end{array}$ & $\begin{array}{c}.75 \\
(.57)\end{array}$ & $\begin{array}{c}.81 \\
(.28)\end{array}$ & $\begin{array}{l}1.57 \\
(.79)\end{array}$ & $\begin{array}{l}.76 \\
(.33)\end{array}$ & $\begin{array}{l}-.01 \\
(.17)\end{array}$ & $\begin{array}{l}1.95 \\
(.81)\end{array}$ & $\begin{array}{l}1.94 \\
(.91)\end{array}$ \\
\hline
\end{tabular}

Sample: 87 MSAs with the largest Black populations. For details see the text.

Note: All regressions are population weighted. See text for details. The instrument used for estimates involves employment growth in the MSA as predicted from the national growth of the local area's industries. For details, see the text. The first stage $R^{2}$ for these estimates is 21 , while the first stage $F$ is 22.4 . 


\section{Table 5}

Share of Total Hours Changes

Accounted for by Population Adjustments

Instrumental Variable Estimates

(Eicher-White Standard Errors in Parentheses)

All Experience Groups

0-9 Years Experience

$\begin{array}{ll}\text { High School } & \text { College } \\ \text { or Less } & \text { or More }\end{array}$

High School College

or Less or more

All Race/Sex Populations

$-.24^{*}$

.79

.73

.92

(1.72)

(.10)

(.13)

(.04)

White Males

$-.27$

.68

(.21)

.86

.86

(2.37)

.79*

(.08)

(.05)

White Females

$1.60^{*}$

(1.20)

$.91^{*}$

1.04*

(.89)

(.22)

(.17)

Black Males

.45

.96

.67

.87

(.17)

(.08)

(.08)

Black Fernales

$\begin{array}{lr}.28 & .85 \\ (28) & (.10)\end{array}$

.52

1.01

(.10)

(.09)

Sample: 132 largest MSAs for the top two rows, 87 MSAs with the largest Black populations for the rest.

Note: All regressions are population weighted. See text for details. Instrument used for estimates involves employment growth in the MSA as predicted from the national growth of local area's industries. With the exception of those estimates indicated with a "*", all first stage F's are above 8. 
Table 6

Relative Demand and Supply

Effects on Relative Wages:

College - High School

Instrumental Variable Estimates

(Eicher-White Standard Errors in Parentheses)

Rel. Supply

(C - HS)

Rel. Demand

(C - HS)

Share of Mfg.

Share of Mfg. + Cons.

$\mathbf{R}^{2}$
$1 \quad 2 \quad 3 \quad 4$

$\begin{array}{llll}-.75 & -.49 & -.51 & -.34\end{array}$

$\begin{array}{llll}(.45) & (.28) & (.24) \quad(.21)\end{array}$

$---\quad .34$

(.20)

$---\quad---\quad-.37$

(.32)

$\begin{array}{llll}-- & -- & -- & -64\end{array}$

(.28)

$\begin{array}{llll}.14 & .14 & .20 & .14\end{array}$

Sample: 132 largest MSAs.

Note: All regressions are population weighted. See text for details. In the IV estimates reported relative supply is treated as endogenous, while all other variables are treated as exogenous. The $\mathrm{R}^{2}$ measures are from reduced-form equations where the relative wage measure is regressed directly on the relevant exogenous variables. Excluded instrument used for IV estimates involves employment growth in the MSA as predicted from the national growth of local area's industries. First stage partial $\mathrm{R}^{2 \text { 's }}$ range from 0.05 to 0.25 , while the first stage F's range from 7.0 to 31.8 . 